\title{
Economic Crisis and Ownership Structure: Evidence from an Emerging Market
}

\author{
Nur İrem Nuhoğlu* \\ Boğaziçi University
}

\author{
Deniz Parlak** \\ Doğuş University
}

\begin{abstract}
It is generally assumed that the corporations in emerging markets are more sensitive to financial distress arising from global crisis than their counterparts in developed countries because of a lower level of institutionalization and governance structure. Parent companies need to build effective corporate governance to overcome the effects of a global economic crisis, considering the drawbacks of an emerging market. The study aims to understand the relation between the capital structure of ultimate parent companies with corporate performance of the affiliates in an emerging market, Turkey, for the period between 2008-2013. The paper divides this period into a pre-economic crisis period of 2008-2010 and a post-economic crisis period of 2011-2013. The ANOVA results revealed that business group affiliates had a higher financial performance and firm value and were more innovative compared to the non-affiliates. The regression analysis showed that the degree of control of the group by the affiliated firm was positively associated with firm value for both the years of crisis and those of recovery periods. The analysis also posits that professionalism in management was positively associated with the affiliates' value in recovery periods. Innovativeness was another variable which contributed positively to value.
\end{abstract}

Keywords: parent company, business group affiliation, Tobin q, TOPSIS, innovativeness, Agency Theory, Turkey. JEL Classification: G32

\section{Ekonomik Krizler ve Sermaye Yapısı: Gelişmekte Olan bir Piyasa Üzerine Uygulama}

\section{Özet}

Genel olarak gelişmekte olan piyasalarda faaliyet gösteren şirketlerin kurumsallaşma düzeyi ve kurumsal yönetim yapısının az gelişmiş olması nedeni ile gelişmiş piyasalardaki şirketlere kıyasla finansal sıkıntılara daha duyarlı olduğu kabul edilmektedir. Holding şirketlerinin gelişmekte olan bir piyasada faaliyet göstermenin dezavantajlarını göz önüne alarak bağlı şirketler üzerinde etkin bir yönetim yapısı kurması gerekmektedir.

\footnotetext{
* Nur İrem Nuhoğlu is a Professor in the Department of Management at Boğaziçi University, 34342, Bebek, İstanbul, Turkey. E-mail: nuhoglun@boun.edu.tr

** Deniz Parlak is an Associate Professor in the Department of Management at Doğuş University, Zeamet Sokak, Acıbadem, İstanbul, Turkey. E-mail: denizp@dogus.edu.tr
} 
Bu çalışmanın amacı gelişmekte olan bir piyasa olan Türkiye'de faaliyet gösteren holdinglerin sermaye yapısı ile bağlı şirketlerin kurumsal performansı arasındaki ilişkiyi 2008-2013 dönemi için incelemektir. Çalışma inceleme dönemini 2008-2010 kriz dönemi ve 2011-2013 dönemi olmak üzere ele almaktadır. Uygulanan ANOVA testi bir holdinge bağlı olarak faaliyet gösteren şirketlerin finansal performansının, şirket değerinin ve innovasyon yeteneğinin bir holdinge bağlı olmayanlara göre daha iyi olduğunu göstermiştir. Regresyon testi ise holdingin bağlı şirket üzerindeki kontrol düzeyi ile bağlı şirket değeri arasında hem kriz hem de kriz sonrası toparlanma döneminde pozitif bir ilişki olduğunu göstermiştir. Aynı analiz yönetimlerin profesyonelleşme düzeyi ile bağlı şirketin değeri arasında toparlanma döneminde doğru yönlü bir ilişki olduğunu kanıtlamıştır. Şirket değerine katkı sağlayan bir diğer değişken de yaratıcılık yeteneğidir.

Anahtar Kelimeler: holding, bağlı şirket, Tobin q, TOPSIS, yaratıcılık, Vekalet Teorisi, Turkiye. JEL Siniflamasi: $G 32$

$\mathrm{T}$ The theory suggests that capital structure may help mitigate agency costs and increase firm value. Prior research posits that the firm's ownership structure is a primary determinant of the content and extent of agency problems between controlling insiders and outside investors, which has a high impact on the valuation of the firm. There is substantial empirical evidence exploring the understanding of the relation between ownership structure and firm value (Morck et al. (1988) and Holderness et al. (1999)). The fact that ownership structure, investment opportunities, and firm value may all be jointly determined creates a primary problem that has been pulling out endogeneity issues (Demsetz and Lehn (1985), Himmelberg et al. (1999), and Demsetz and Villalonga (2001)). Most of the prior research is based on the samples of well-developed countries like the USA, and considers the general aspects of the ownership structure.

In this context, the paper aims to focus on the impact of an ultimate parent company on the financial performance, innovativeness, and value of the affiliated firm in an emerging economy, Turkey, which is perceived as a rising star in the world economy. It is generally assumed that the corporations in emerging markets are more sensitive to financial distress arising from global crisis than their counterparts in developed countries because of their lower levels of institutionalization and governance structure. Parent companies need to build effective corporate governance to overcome the effects of a global economic crisis, considering the drawbacks of an emerging market. The issue in this paper lies in the discussion of the attitude of a business group as the main insider and its effect in overcoming crisis. The ultimate parent company may control corporate assets by diverting resources for the benefits of the business group or, in contrast, by diverting the resources of the parent company to the affiliated firm which may improve and maximize the value of the affiliate given that the affiliate is a good performer. The empirical issue of the paper is to understand the presence of the controlling shareholder, the business group that has both costs and benefits to the firm, and the net effect of the controlling shareholder on corporate performance. Studies addressing this issue have been increasing rapidly in the past few years. However, so far the analysis is incomplete 
and general conclusions cannot be drawn because of the fact that most of the studies are based on only one group of countries, i.e. the USA, and other developed economies. Research on emerging economies is still limited (Claessens et al., 2000) and most of it is in comparable country studies where differences in legal, taxation and accounting rules as well as institutional frameworks are not controlled. As shown in La Porta et al. (1997) and Bebchuk (1999), the quality of the legal rules and enforcement affects the level of the expropriation problems. This paper takes an alternative approach in the way that the analysis focuses on a given country. In this context, the legal regime and the country specific factors are held constant, which allows us to investigate the effects of ownership concentration more precisely by comparing the results of two groups of public manufacturing and service companies: those controlled by a business group and others as stand-alones.

The primary purpose of the study is to investigate and understand the differences in financial performances and firm values of business group affiliated firms and stand-alones in an emerging economy and provide guidance for other similar emerging markets. The paper stems from the assumptions of business group affiliated firms that have higher financial performance, higher firm value, and are more innovative than non-affiliated counterparts both in an economic downturn and in recovery periods. The study also assumes that there is a positive association between the firm value and the degree of innovativeness of business group affiliated firms, between the value of the affiliated firm and the degree of diversification of the business group, between the value of the affiliated firm and the degree of control of the business group on the affiliated firm, and the value of the affiliated firm and the degree of professionalism in management of the affiliated firm both in an economic downturn and a recovery period. The analysis covers a period of 6 years between 2008 and 2013. The years between 2008 and 2010 are presumed to be the period of economic crisis and the years between 2011 and 2013 are the recovery period. The analysis covered two sub-periods; the first sub-period is defined as the crisis period and the second the recovery period. In literature, the period of 2008-2010 is perceived as the Irish banking crisis or subprime crisis.

The hypotheses developed for the study rely on the assumptions that business group affiliated firms have a higher financial performance and higher firm value than non-affiliated firms and they are more innovative than stand-alones. The study explores whether there is a positive association between firm value and the degree of innovativeness of business group affiliated firms and between the value of the affiliated firm and the degree of diversification of the business group. The study proceeds with the exploration of the association between the value of an affiliated firm and the degree of control of the business group on the affiliated firm.

The sample consisted of 191 manufacturing and service public firms in Turkey, of which 126 firms were business group affiliates and 68 non-affiliates. An analysis of variance test revealed that business group affiliates had a higher financial performance and firm value for all two sub-periods; with regard to innovativeness, no significant difference was found between the two groups. The regression analysis showed that the degree of control of the group on the affiliated firm measured with percentage of 
ownership of the business group was positively associated with the firm value for the periods of crisis. The analysis also posits that the control of the ultimate parent company or business group over the affiliated firm measured with the percentage of family board members was negatively and the percentage of ownership of the business group was positively associated with the affiliates' value in recovery periods. Innovativeness measured with the number of licenses and/or patents attained was another variable which contributed positively to the value.

In the next section of the paper, we provide background information and present our research issues with hypothesis development, followed by a section discussing the methodology used to address our research issues of interest. We then discuss the results of our study and conclude by discussing the implications of our results, limitations of our work, and suggestions for future research.

\section{Theoretical Background}

The past fifty years witnessed an important debate in academic literature about the connection between ownership structure and financial performance. In emerging economies, due to the existence of frequent market failures and weak legal and regulatory institutions, the dominant ownership structures are business groups (Carney et. al., 2011). Khanna and Rivkin defined business groups as "firms which though legally independent are bound together by a constellation of formal and informal ties and which are accustomed to take coordinated action".

Ownership structures of emerging and transition markets' firms are quite different from that of firms in developed economies. In emerging economies, capital markets are less developed and mostly dominated by large foreign shareholders and block-holders (Sytse et al., 2002). Hence, the stock market capitalization rate is low, and diffused ownership is rather an exception than the norm; consequently corporate governance mechanisms are weak (La Porta et al., 1999).

In these contexts, emerging market economies are dominated by large business groups in which, though member firms remain independent, strong economic and social ties unite group affiliates (Khanna and Rivkin, 2001). The strategy and related decisions are made at the group level and, in the absence of a reliable legal infrastructure, the transactions in both input and product markets are internalized (Carney at all, 2011; Khanna and Rivkin, 2001).

An important outcome of large business groups is the presence of internal capital markets. Still, the developed market field studies on internal capital markets reveal conflicting results. Williamson (1975) and Donaldson (1984) suggest that diversified firms profit from interdependence among otherwise completely unrelated investment projects, and the presence of internal capital markets helps headquarters to channel its scarce resources to more profitable investment opportunities which results in a diversification premium. Seemingly, Stein (1997) concludes that the presence of internal capital markets allows headquarters to invest in more profitable projects by using their controlling rights. On the opposite side, Lamont (1997), Scharfstein (1998), and 
Shin and Stulz (1998) concluded that cross-subsidization in diversified firms leads to inefficient capital allocation. Berger and Ofek (1995) and Rajan et al. (2000) showed that inefficient capital allocation of internal capital markets reduces the diversified firm value. Hovakimian (2009) finds that during non-recession periods, when external capital markets are easier to access, internal capital markets tend to be inefficient, whereas during recessions, when external capital markets are more restrictive, conglomerates significantly enhance the efficiency of internal capital markets by shifting more capital to high growth segments relative to low growth ones. Emerging markets are characterized by information asymmetry, and agency problems originate from imperfect capital markets. Desai, Foley and Hines (2004) found that multinational firms appear to employ internal capital markets opportunistically to overcome imperfections in external capital markets. Shin and Park (1999) argue that the internal capital market reduces the financing constraints of the Korean chaebols.

While business groups take different names in different countries, there is a consensus in the academic world on their contribution to a home country economy. Still, empirical evidence on the performance of business groups and member firms is mixed. An important characteristic of business groups is their high degree of unrelated diversification. Many empirical studies showed that diversification strategies of most business groups have dissipated instead of creating shareholder value (Weyni, 2004). However, some scholars argue that large business groups are a source of value in emerging markets because they tend to overcome market inefficiencies. Similarly, some empirical studies show that group affiliation, group size and diversification serve as important factors that create value in emerging markets (Khanna and Palepu, 1997).

Among many factors which affect financial performance and firm value of affiliated firms of business groups, innovativeness takes the first place. Business groups represent a kind of network where member firms can exchange resources and cooperate to enhance their innovative capabilities (Khanna and Palepu, 1997). At the same time, as stated above, business groups are able to enhance their value due to their ability to create their own internal capital markets to overcome the difficulties arising from outside financing. These internal capital markets are especially important for innovation given the fact that a stand-alone firm needs to turn to financial market intermediaries to finance its research and development activities, whereas a group-affiliated firm can rely on the group internal capital market where information asymmetry is minimized (Himmelberg and Peterson (1994). Another important factor that contributes to firm performance is professionalism in management. Villalonga and Amit (2004) find that family ownership creates value only when it is combined with certain forms of family control and management. Family management is contributory only when independent members take a role in the management of the company. Bhagat and Bolton (2008) analyze the relationship between corporate governance and performance by taking into account the inter-relationships among corporate governance, corporate performance, corporate capital structure, and corporate ownership structure. They conclude that the separation of ownership and management is positively and board independence is negatively correlated with better contemporaneous and subsequent operating performance. Even if no correlation was 
found between governance and value, the authors showed that better governed firms were less likely to experience disciplinary management turnover in spite of their poor performance.

The aim of this paper is to search for the impact of Turkish business groups on the value and financial performance of their affiliated companies and to discover the factors that contribute to firm value. The history of business groups in Turkey goes back to the 1960s. In those years the government gave substantial subsidies to business group formations with the changes it made in trade and tax legislations (Üsdiken, 2008). These groups, which were mostly established by families and called holdings (ultimate parent companies) in local terminology, have dominated a large part of the Turkish economy for the past 50 years. Although many of the groups went public in the last two decades, the top level managers and board members are still family members and there are few independent members on the board of directors. The empirical research showed that family members left their boards of directors' seats to independent members only in the presence of legal constraints or when they sold a part of their shares to foreign or domestic partners. The strategic decisions were made at the holding level and were dictated to affiliated firms (Üsdiken and Oktem, 2008).

The paper has important contributions to the existing literature. First, it aims to measure the performance not of business groups but of member firms, which is an important gap in the literature. Second, it not only addresses the comparison of value and performance of group affiliated and non-affiliated firms but also searches for factors that contribute to value; hence, it tries to make a complete picture of the phenomenon. Finally, it adds professional management and ownership control perspectives to the research on business groups.

\section{Hypotheses Development}

The primary purpose of the study is to investigate and understand the differences in financial performances and firm values of business group affiliated firms and standalones. As stated in the literature review section, in emerging markets the business group affiliated firms have a comparative advantage because of the possibility of internalizing transactions in input and product markets in the lack of reliable legal infrastructure and corporate governance mechanisms and because of the ability to create their internal capital markets to finance profitable projects. In two previous studies Khanna and Palepu (2000a, 2000b) showed that affiliates of the most extensively diversified business groups outperformed unaffiliated firms both in Chile and India. Similarly Khanna and Rivkin (2001) analyzed 14 emerging market firms and concluded that in 12 of the 14 countries group affiliation appears to have as profound an effect on profitability.

Consequently, the following two hypotheses are formulated:

$\mathbf{H}_{1}:$ Business group affiliated firms have a higher financial performance than non-affiliated counterparts both in an economic downturn and in recovery periods.

$\mathbf{H}_{2}$ : Business group affiliated firms have a higher firm value than non-affiliated counterparts both in an economic downturn and in recovery periods. 
Business group members have the possibility of exchanging resources and cooperating to enrich their innovation capabilities. Teece (1996) argued that in the presence of imperfect external markets, groups can facilitate innovation by providing institutional infrastructure such as internal capital markets. Hobday (1995) concluded that business reputations and government ties attract foreign technology providers and Claessens et al. (2000) found that concentrated ownership provided long-term perspectives on R\&D investments. From these premises emerges the next hypothesis of the study:

\section{$\mathbf{H}_{3}$ : Business group affiliated firms are more innovative than non-affiliated} counterparts both in an economic downturn and in recovery periods.

The second purpose of the study was to find out the factors that contributed to long term performance, hence the firm value of group affiliated firms. The literature review reveals that the main variables that affected firm values are the degree of innovativeness of the company, the degree of diversification of the group, and the degree of control of the group over the affiliated firm.

Previous studies concluded that the innovativeness capability is an important factor that contributes to competitiveness and consequently to the firm value. Damanpour and Evan (1984) found a positive relationship between innovation and performance; similarly, Subramanian and Nilakanta (1996) reported that innovativeness had a positive effect on organizational performance as measured by the return on assets. Hence the fourth hypothesis is stated as follows:

\section{$\mathbf{H}_{4}:$ There is a positive association between the firm value and the degree of innovativeness of business group affiliated firms both in an economic downturn and in recovery periods.}

The last 20 years' studies found a negative association between the firm value and diversification in developed economies such as the U.S., the U.K., Germany, and Japan (Lang and Stulz, 1994; Berger and Ofek, 1995; Servaes 1996; and Lins and Servaes, 1999). The evidence suggests that, for the firms operating in developed capital markets, the costs of diversification outweigh the benefits. In a recent study Kuppuswamy and Villalonga (2015) documented that the value of corporate diversification increased during the 2007-2009 financial crisis as diversification gave firms both financing and investment advantages. They concluded that conglomerates' access to internal capital markets became more valuable not just because external capital markets became more costly, but also because the efficiency of internal capital allocation increased significantly during the crisis. It was found that, in the presence of market imperfections, agency problems, and information asymmetry, large diversified business groups are a source of value in emerging markets as they decrease the business risk by stabilizing market inefficiencies and creating their own internal capital markets (Stein 1997, Khanna and Palepu 1997). Fauver et al. (2001) in their study conducted on 35 countries concluded that in low-income and low-GDP countries, diversification is not harmful to shareholder wealth, but could be beneficial. Based on these premises, the fifth hypothesis is formulated as follows: 
$\mathbf{H}_{5}$ : There is a positive association between the value of an affiliated firm and the degree of diversification of the business group both in an economic downturn and in recovery periods.

Business groups are able to enhance their value due to their ability to create their own internal capital markets to overcome the difficulties arising from outside financing. Furthermore the affiliated firms' access to internal capital markets increases with the increasing ownership of the ultimate parent company. Another important factor that contributes to firm performance is professionalism in management. Family management is contributory only when independent members take a role in the management of the company. Torben and Thomsen (2000) examined the relationship between ownership structure and value of the largest European firms. They found that ownership concentration has a positive effect on firm when the largest owner is a financial institution or another corporation. If the largest owner is a family or a single individual, ownership concentration has no effect on firm value, and the effect is negative if the largest owner is a government organization. Owner-identity matters, particularly in a continental European institutional setting where ownership concentration is high and minority investor protection is low. Lins (2003) analyzed a sample of 1433 firms from 18 emerging markets and concluded that large non-management control rights that block holdings are positively related to firm value and the effects are significantly more pronounced in countries with low shareholder protection. Hence the sixth and seven hypotheses are defined as follows:

$\mathbf{H}_{6}$ : There is a positive association between the value of an affiliated firm and the degree of control of the business group on the affiliated firm both in an economic downturn and in recovery periods.

$\mathbf{H}_{7}:$ There is a positive association between the value of an affiliated firm and the degree of professionalism in management of the affiliated firm both in an economic downturn and in recovery periods.

\section{Research Methodology}

To test the hypotheses of this study, the Turkish service and manufacturing sector firms are analyzed. Due to the availability of data, only those firms which are quoted in the Istanbul Stock Exchange are included in the sample. As of December 2013, there were 235 manufacturing and service industry firms listed in the national stock exchange market. As the analysis covered the period between 2008 and 2013, the firms that went to public after 2008 and those that were dropped from the quote list after 2010 were left out of the analysis. The final sample consisted of a total of 191 firms, of which 44 were service and 147 were manufacturing sector firms.

The firms in the sample are categorized as business group affiliates and non-affiliates according to their ownership structure. A firm is defined as a business group affiliate if the principal owner is a holding company and if its share in the company exceeds 50 percent of the shares not offered to the public. All other firms are classified as stand-alones. The data about business group affiliation for the firms in the sample was obtained from the 
website of the Public Disclosure Platform. The Public Disclosure Platform (PDP) is an electronic system through which electronically signed notifications required by the Capital Market Board of Turkey and Borsa Istanbul regulations are publicly disclosed (www.kap.gov.tr).

The distribution of the sample according to business group affiliation, size measured with sales volume, and sector is presented in Table 1.

Table 1

Sample

\begin{tabular}{|c|c|c|c|c|}
\hline & \multicolumn{4}{|c|}{ sales volume (\$) } \\
\hline & $\begin{array}{l}\text { smaller than } \\
\text { \$100 mn }\end{array}$ & $\begin{array}{c}\text { between } \\
\$ 100 \text { mn -\$ } 1 \text { bn }\end{array}$ & $\begin{array}{l}\text { greater than } \\
\qquad \$ 1 \text { bn }\end{array}$ & total \\
\hline \multicolumn{5}{|l|}{ Manufacturing } \\
\hline affiliated & 32 & 49 & 16 & 97 \\
\hline non affiliated & 30 & 17 & 3 & 50 \\
\hline \multicolumn{5}{|l|}{ Service } \\
\hline affiliated & 9 & 11 & 6 & 26 \\
\hline non affiliated & 8 & 6 & 4 & 18 \\
\hline Total & 79 & 83 & 29 & 191 \\
\hline
\end{tabular}

The analysis covers a period of 6 years between 2008 and 2013. The years between 2008 and 2010 are presumed to be the period of economic crisis and the years between 2011 and 2013 are the recovery period. The analysis covered two sub-periods; the first sub-period is defined as the crisis period and the second as the recovery period.

The study had two stages. At the first stage the firm value, financial performance and innovativeness of business group affiliates and those of stand-alones are compared.

In finance literature the financial performance of a firm is measured through a set of financial ratios which give insights about the company in an organized way and enable the comparison of different firms. The ratios are classified according to the information they provide. The main areas of measurement are liquidity, profitability, growth, leverage and risk of a company. In the context of this study, five financial ratios are used to measure the five dimensions mentioned above. Profitability is measured with return on assets (ROA), liquidity with current ratio (CR), leverage with debt equity ratio (DE), growth with sales growth (SG) and risk (RS) with standard deviation of return on assets. Return on assets is defined as net income and financial expenses divided by total assets, current ratio as current assets divided by current liabilities, and debt equity ratio as long and short term liabilities divided by total equity. The balance sheets and income statements of the firms in the sample are obtained from the website of the PDP and the average ratios were calculated thereupon for six years between 2008 and 2013.

To rank 191 companies in the sample according to their financial performance, "The Technique for Order of Preference by Similarity to Ideal Solution (TOPSIS)" method 
is applied. In this method, two artificial alternatives are hypothesized. The first is the ideal alternative in which the one that has the best level for all attributes is considered and the second one is the negative ideal alternative which is the one that has the worst attribute values. TOPSIS selects the alternative that is the closest to the ideal solution and farthest from the negative ideal alternative.

To apply TOPSIS, " $\mathrm{m}$ " alternatives (options) and " $\mathrm{n}$ " attributes/criteria should be selected and the score of each option with respect to each criterion should be calculated. After the identification of alternatives and options TOPSIS is applied at 5 stages: construction of the normalized decision matrix, construction of the weighted normalized decision matrix, determination of the ideal and negative ideal solutions, calculation of the separation measure for each alternative, and computation of the relative closeness to the ideal solution which is defined as "c" value (Uygurturk and Korkmaz, 2012).

In the context of this analysis in the calculation of a "c" score, which is the measure of the overall financial performance of the firms, equal weights are given to each of the four criteria which are the four financial performance measures.

The firm value (FV) is measured with Tobin q. Tobin q ratio is calculated by dividing the market value of a firm by the replacement cost of the firm. The market value of the firm is the sum of the values of the common stock, preferred stock, long-term debt, and short-term debt net of assets. The book value of the capital includes the net plant, property and equipment, inventories, investments in unconsolidated subsidiaries, and intangibles (other than research and development). To overcome the difficulties of measuring Tobin q, Chung and Pruitt (1994) proposed the following approximation:

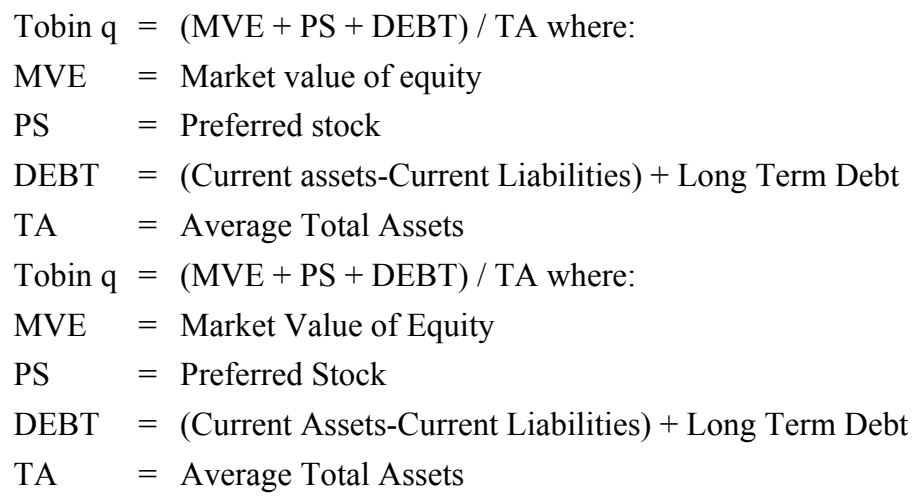

Chung and Pruitt's approximation is used to measure Tobin q; the market value of equity is calculated by taking the closing prices of the last trading days of the six years of the analysis. The data for preferred stock and closing prices of shares was obtained from the bulletins of the Istanbul Stock Exchange, and all other data from the balance sheets and income statements obtained from the website of the PDP.

Innovativeness is an important attribute that shapes the success of a firm in the business world. Two measures, the number of licenses and/or patents (PT) and the ratio of research and development expenses to sales (RD), are used as proxies for innovativeness. The data for patents are obtained from the Turkish Patent Institute and 
the data for $\mathrm{RD}$ is obtained from income statements of companies in the sample. The financial performance, firm value and innovativeness of business group affiliated and stand-alone firms are compared with the analysis of variance (ANOVA) method.

At the second stage of the analysis the factors that contributed to firm value are analyzed. Consistent with the literature review, the degree of innovativeness of the affiliated company, the degree of diversification of the business group and the degree of control of the group over the affiliated firm are defined as the main variables affecting value. As in the previous stage, the degree of innovativeness is measured by the number of licenses and/or patents (PT) and the ratio of research and development expenses to sales (RD).

The degree of control of the business group is computed with the measured ownership percentage (OP), which is defined as the percentage of shares not open to the public of the affiliated company controlled by the business group. Professionalism in management is measured with the percentage of business group family members (FM) that have seats in the board of directors. All other members are assumed to be independent professionals. The data for the board of director membership is obtained from the website of the Istanbul Stock Exchange and the relationship of the members with the family is further investigated through social media, direct contact and web search. The last factor, which is the diversification (DIV) of a holding company, is measured with the amount of sales attributed to the largest sector relative to the total sales of the holding company. Finally, two control variables, one for size and the other for sector, are added to the analysis. Size (FS) is measured with the natural logarithm of firm sales. SC is a dummy variable where 0 denotes service and 1 manufacturing sector.

The association between dependent variable (FV) and independent variables (PT, $\mathrm{RD}, \mathrm{FM}, \mathrm{OP}, \mathrm{DIV}, \mathrm{FS}$ and SC) is analyzed with the regression method. The regression equation is as follows:

\begin{tabular}{|c|c|c|}
\hline FV & $=$ & $\alpha+\mathrm{aPT}+\mathrm{bRD}+\mathrm{cFM}+\mathrm{dOP}+\mathrm{eDIN}+\mathrm{fFS}+\mathrm{g} \mathrm{SC}+\varepsilon$ where: \\
\hline FV & $=$ & Firm Value \\
\hline PAT & $=$ & Number of Licenses and/or Patents \\
\hline $\mathrm{RD}$ & $=$ & Research and Development Expenses \\
\hline FM & $=$ & Percentage of Family Members in Board of Directors \\
\hline $\mathrm{OP}$ & $=$ & Ownership Percentage of Business Group \\
\hline DIV & $=$ & Degree of Diversification of the Holding Company \\
\hline SIZE & $=$ & Size of the Group \\
\hline IND & $=$ & Sector ( 0 for service industry and 1 for manufacturing industry) \\
\hline
\end{tabular}

\section{Analysis and Results}

As stated in the previous section, the sample consists of 191 firms of which 147 are manufacturing and 44 are of service industry firms. As a preliminary analysis, the two industries' financial performances measured with "c" value, market values measured with Tobin q, innovativeness measured with research and development expenses ratio, and numbers of patents received are compared. The ANOVA analysis revealed that for 
the first sub-period, which is the period of crisis, the service industry outperformed the manufacturing industry in financial performance, firm value and innovativeness measured with the RDexpense ratio. The difference however is statistically significant only for financial performance and innovativeness. For the second sub-period, the only statistically significant difference is observed for the RDt expense ratio; for all other variables the two industries performed equally. The results are presented in Tables 2 and 3.

Table 2

Financial Performance Differences 2008-2010

\begin{tabular}{l|c|c|c|c|c|c|c|c|c}
\hline \multicolumn{1}{c}{ manufacturing } & \multicolumn{3}{c}{ service } & \multicolumn{2}{c}{ mean difference } \\
no of firms & variables & mean & $\min$ & $\max$ & mean & $\min$ & $\max$ & $\mathrm{f}$ value & sign \\
\hline $\begin{array}{l}\text { financial } \\
\text { performance }\end{array}$ & $\mathrm{c}$ & 0.11 & 0.00 & 0.25 & 0.30 & 0.00 & 0.56 & 4.85 & 0.03 \\
\hline market value & $\mathrm{tq}$ & 0.63 & -0.21 & 4.82 & 0.73 & -0.60 & 2.76 & 0.65 & 0.42 \\
\hline innovativeness & $\mathrm{rd}$ & 0.05 & 0.00 & 0.08 & 0.19 & 0.00 & 0.49 & 4.37 & 0.04 \\
\hline & $\mathrm{pat}$ & 0.87 & 0.00 & 81.67 & 0.01 & 0.00 & 0.33 & 0.69 & 0.41 \\
\hline
\end{tabular}

Table 3

Financial Performance Differences 2011-2013

\begin{tabular}{|c|c|c|c|c|c|c|c|c|c|}
\hline \multirow{3}{*}{ no of firms } & \multicolumn{4}{|c|}{ manufacturing } & \multicolumn{3}{|c|}{ service } & \multicolumn{2}{|c|}{ mean difference } \\
\hline & & & 147 & & & 44 & & & \\
\hline & variables & mean & $\min$ & $\max$ & mean & $\min$ & $\max$ & f value & Sign. \\
\hline $\begin{array}{l}\text { financial } \\
\text { performance }\end{array}$ & c & 0.01 & 0.00 & 0.35 & 0.02 & 0.01 & 0.33 & 0.38 & 0.54 \\
\hline market value & $\mathrm{tq}$ & 0.85 & -0.18 & 7.85 & 0.83 & -0.10 & 6.84 & 0.01 & 0.91 \\
\hline \multirow{2}{*}{ innovativeness } & rd & 0.00 & 0.00 & 0.05 & 0.01 & 0.00 & 0.29 & 3.79 & 0.05 \\
\hline & pat & 1.41 & 0.00 & 83.00 & 0.28 & 0.00 & 10.67 & 0.85 & 0.36 \\
\hline
\end{tabular}

As statistically significant mean differences are found for two out of four variables in the first sub-period and for one out of four variables in the second sub-period, an industry dummy is encountered for the remainder of the study. To compute and compare the overall financial performance of the companies, the TOPSIS analysis, a multi-criteria decision making method, is applied. The four financial performance measures are defined as four decision criteria (consistent with the literature) are assumed to be equally important. Hence equal weights are given to each criterion. The summary results for ratios, weights, and "c" values for both sub-periods are presented in Table 4. 
Table 4

\section{TOPSIS Results}

\begin{tabular}{l|l|l|l|l|l|l|l|l|l}
\hline & \multicolumn{1}{c}{ ROA } & CR & DR & RS & & ROA & CR & DR & RS \\
& mean & mean & mean & mean & & mean & mean & mean & mean \\
\hline ratios & 0.04 & 2.47 & 0.48 & 0.05 & ratios & 0.04 & 2.73 & 0.48 & 0.05 \\
\hline weights & 0.25 & 0.25 & 0.25 & 0.25 & weights & 0.25 & 0.25 & 0.25 & 0.25 \\
\hline & mean & max & min & & & mean & max & min & \\
\hline c value & 0.02 & 0.96 & 0.00 & & c value & 0.02 & 0.35 & 0.00 & \\
\hline
\end{tabular}

The minimum "c" value is 0.00 , the maximum is 0.96 and the mean is 0.02 for the first sub-period whereas it is $0.00,0.35$, and 0.02 respectively for the second sub-period. The descriptive statistics for the computed Tobin q's, PAT and RD are presented in Table $\mathrm{V}$. The sample mean for Tobin q is 0.65 for the first sub-period and 0.84 for the second sub-period. The mean for RD expense ratios for the two sub-periods are 0.8 percent and 0.6 percent. Finally, the mean number of licensed patents is 0.67 for the first and 1.15 for the second sub-periods. Table 5 reveals both the descriptive statistics and the results of the ANOVA analysis.

Table 5

Mean Differences I

\begin{tabular}{|c|c|c|c|c|c|c|c|c|c|c|c|c|c|c|}
\hline & \multicolumn{7}{|c|}{ 2008-2010 average } & \multicolumn{7}{|c|}{ 2011-2013 average } \\
\hline & group & $\mathbf{N}$ & Mean & Min & Max & $\mathbf{F}$ & Sig. & group & $\mathbf{N}$ & Mean & Min & $\operatorname{Max}$ & $\mathbf{F}$ & Sig. \\
\hline \multirow{3}{*}{ c } & $\begin{array}{l}\text { non- } \\
\text { affiliated }\end{array}$ & 69 & 0.01 & 0.00 & 0.05 & \multirow{3}{*}{2.91} & \multirow{3}{*}{0.09} & $\begin{array}{l}\text { non- } \\
\text { affiliated }\end{array}$ & 68 & 0.01 & 0.00 & 0.10 & \multirow{3}{*}{2.76} & \multirow{3}{*}{0.10} \\
\hline & affiliated & 122 & 0.02 & 0.00 & 0.56 & & & affiliated & 123 & 0.02 & 0.00 & 0.35 & & \\
\hline & Total & 191 & 0.02 & 0.00 & 0.56 & & & Total & 191 & 0.02 & 0.00 & 0.35 & & \\
\hline \multirow{3}{*}{ tq } & $\begin{array}{l}\text { non- } \\
\text { affiliated }\end{array}$ & 69 & 0.48 & -0.26 & 2.76 & \multirow{3}{*}{6.66} & \multirow{3}{*}{0.01} & $\begin{array}{l}\text { non- } \\
\text { affiliated }\end{array}$ & 68 & 0.61 & -0.09 & 3.72 & \multirow{3}{*}{5.26} & \multirow{3}{*}{0.02} \\
\hline & affiliated & 122 & 0.75 & -0.60 & 4.82 & & & affiliated & 123 & 0.97 & -0.18 & 7.85 & & \\
\hline & Total & 191 & 0.65 & -0.60 & 4.82 & & & Total & 191 & 0.84 & -0.18 & 7.85 & & \\
\hline \multirow{3}{*}{$\mathrm{rd}$} & $\begin{array}{l}\text { non- } \\
\text { affiliated }\end{array}$ & 69 & 0.00 & 0.00 & 0.05 & \multirow{3}{*}{0.96} & \multirow{3}{*}{0.33} & $\begin{array}{l}\text { non- } \\
\text { affiliated }\end{array}$ & 68 & 0.01 & 0.00 & 0.14 & \multirow{3}{*}{0.00} & \multirow{3}{*}{0.97} \\
\hline & affiliated & 122 & 0.01 & 0.00 & 0.49 & & & affiliated & 123 & 0.01 & 0.00 & 0.29 & & \\
\hline & Total & 191 & 0.01 & 0.00 & 0.49 & & & Total & 191 & 0.01 & 0.00 & 0.29 & & \\
\hline \multirow{3}{*}{ pat } & $\begin{array}{l}\text { non- } \\
\text { affiliated }\end{array}$ & 69 & 0.14 & 0.00 & 7.00 & \multirow{3}{*}{0.85} & \multirow{3}{*}{0.36} & $\begin{array}{l}\text { non- } \\
\text { affiliated }\end{array}$ & 68 & 0.24 & 0.00 & 9.00 & \multirow{3}{*}{1.73} & \multirow{3}{*}{0.19} \\
\hline & affiliated & 122 & 0.97 & 0.00 & 81.67 & & & affiliated & 123 & 1.65 & 0.00 & 83.00 & & \\
\hline & Total & 191 & 0.67 & 0.00 & 81.67 & & & Total & 191 & 1.15 & 0.00 & 83.00 & & \\
\hline
\end{tabular}


Both firm values measured with Tobin $\mathrm{q}$ and financial performance measured with "c" value of business group affiliated firms is higher than that of stand-alones for all two sub-periods. The difference is statistically significant at 5 and 10 percent confidence levels, so hypotheses one and two are certainly supported.

With the criteria of measurement of innovativeness, the business group affiliated firms' results are higher than that of the non-affiliated firms' results, but the difference is not statistically significant for both sub-periods. The results are not surprising for the analysis of PAT which denotes number of licenses and/or patents. Firms hesitate to apply to the State Patent Institute for licensing their innovations due to the extensive paper work requirements and high costs in Turkey. Hence, the mean number of patents is very low, which distorts the reliability of the measurement.

The analysis is extended by dividing business affiliated firms into three sub-groups. The first sub-group consists of local affiliated firms, the second sub-group of foreign affiliated firms and the third sub-group of foreign and local mergers. The ANOVA results are presented in Table 6.

Foreign affiliated firms are the best performers whereas stand-alones are the worst performers for firm value measured with Tobin $\mathrm{q}$ and financial performance measured with "c" for both sub-periods. The difference is statistically significant at 1 percent and 5 percent confidence levels, hence hypotheses one and two are supported (Table VI).

The mean difference for the two measures of innovativeness is not statistically significant neither for the crisis period nor for the recovery years. For the RD expense ratio, the foreign affiliated firms are the worst performers for both sub-periods. These results are not surprising as foreign firms have the tendency to centralize their research and development operations in their home countries. Stand-alones being the lowest patent holders can again be explained with high costs and a high level of bureaucracy associated with patent licensing during the application process.

The factors that contributed to the firm value of business group affiliated firms are investigated at the second stage of the analysis. The descriptive statistics for the two measures of innovativeness, for the two measures of group control, for the single measure of diversification and for that of size are presented in Table 7.

The sample mean for diversification is 21 percent for the first and 27 percent for the second sub-periods; for family members on the board of directors the mean increased from 63 percent during the 2008-2010 period to 64 percent during the 2011-2013 period, and finally for ownership percentage of the business group in the affiliated firms, the mean which was 69 percent in the first sub-period increased to 78 percent in the second sub-period.

The results of the regression analysis are presented in Table 8 .

For the entire model, multicollinearity is checked with tolerance and variance inflation factor (VIF) statistics. All VIF values are below 2.5, which lead to the conclusion that there is no multicollinearity in this analysis. 
Table 6

Mean Differences II

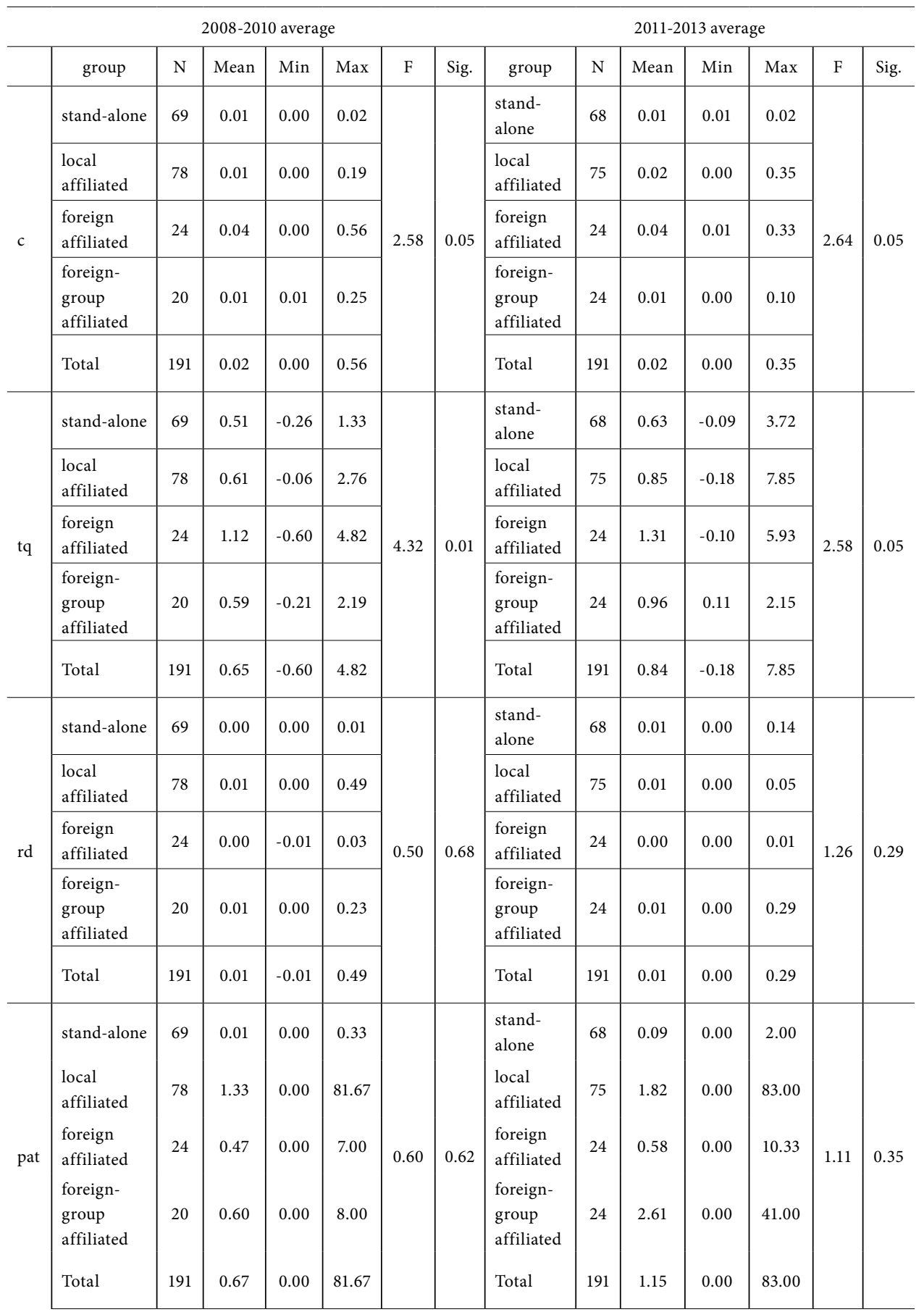


Table 7

Descriptive Statistics

\begin{tabular}{l|c|c|c|l|c|c|c}
\hline \multicolumn{3}{|c|}{$2008-2010$} & \multicolumn{3}{c}{$2011-2013$} \\
\hline PAT & Mean & Min & Max & & Mean & Min & Max \\
\hline RD & 1.04 & 81.67 & 0.00 & PAT & 1.75 & 83.00 & 0.00 \\
\hline DIV & 0.01 & 0.49 & 0.00 & RD & 0.01 & 0.29 & 0.00 \\
\hline FM & 0.21 & 0.99 & 0.01 & DIV & 0.27 & 0.99 & 0.01 \\
\hline OP & 0.63 & 1.00 & 0.00 & FM & 0.64 & 1.00 & 0.00 \\
\hline SIZE & 0.69 & 1.00 & 0.31 & OP & 0.78 & 1.00 & 0.22 \\
\hline
\end{tabular}

Table 8

Regression Results

\begin{tabular}{|c|c|c|c|c|c|c|c|c|c|c|c|c|}
\hline \multicolumn{6}{|c|}{ dependent variable : tobin $q$} & \multicolumn{7}{|c|}{ dependent variable : tobin $q$} \\
\hline & \multicolumn{2}{|c|}{ coefficients } & sign & \multicolumn{2}{|c|}{ coll. stat. } & & \multicolumn{2}{|c|}{ coefficients } & \multicolumn{2}{|c|}{ sign } & \multicolumn{2}{|c|}{ coll. stat. } \\
\hline & B & $\begin{array}{l}\text { Std. } \\
\text { Error }\end{array}$ & & TOL & VIF & & B & $\begin{array}{l}\text { Std. } \\
\text { Error }\end{array}$ & & & TOL & VIF \\
\hline Constant & 0.49 & 0.18 & 0.01 & & & Constant & 18.69 & 0.52 & 0.00 & & & \\
\hline $\mathrm{rd}$ & 1.38 & 1.27 & 0.28 & 0.97 & 1.03 & rd & -6.56 & 6.24 & 0.29 & & 0.97 & 1.03 \\
\hline gown & 0.37 & 0.13 & $0.01 \quad *$ & 0.41 & 2.41 & gown & 1.22 & 0.63 & 0.054 & $* * *$ & 0.77 & 1.30 \\
\hline $\mathrm{fm}$ & -0.03 & 0.23 & 0.90 & 0.42 & 2.40 & $\mathrm{fm}$ & -1.51 & 0.76 & 0.048 & $* *$ & 0.86 & 1.16 \\
\hline pat & 0.00 & 0.01 & 0.84 & 0.98 & 1.02 & pat & 0.06 & 0.02 & 0.007 & $*$ & 0.97 & 1.03 \\
\hline ind & 0.11 & 0.12 & 0.38 & 0.94 & 1.06 & ind & 0.04 & 0.36 & 0.90 & & 0.95 & 1.05 \\
\hline size & -0.02 & 0.01 & $0.00 *$ & 0.54 & 1.87 & size & 0.04 & 0.02 & 0.064 & $* * *$ & 0.42 & 2.39 \\
\hline $\operatorname{div}$ & -0.51 & 0.32 & 0.11 & 0.76 & 1.31 & div & 0.29 & 0.20 & 0.14 & & 0.68 & 1.46 \\
\hline R square & 0.08 & & & & & $\mathrm{R}$ square & 0.14 & & & & & \\
\hline$*$ & signif & nt at $1 \%$ & confidence l & & & $\begin{array}{l}* \\
* * \\
* * *\end{array}$ & $\begin{array}{l}\text { signif } \\
\text { signif } \\
\text { signif }\end{array}$ & $\begin{array}{l}\text { Int at } 1^{\circ} \\
\text { int at } 5^{\circ} \\
\text { int at } 10\end{array}$ & $\begin{array}{l}\text { confid } \\
\text { confid } \\
\text { conf }\end{array}$ & $\begin{array}{l}\text { ce leve } \\
\text { ce leve } \\
\text { ice les }\end{array}$ & & \\
\hline
\end{tabular}

For the first sub-period the only statistically significant variables are group ownership percentage and size. As expected, the sign of group ownership percentage is positive implying that firm value increases when the group has more control over the firm. Hence, hypothesis six is supported. Hypotheses four, five and seven are rejected based on the fact that the variable that measures group diversification, the variable that measures innovativeness and the variable that measure professionalism in management, are not statistically significant. The control variable size is significant; the coefficient is negative showing that smaller groups perform better in times of crisis. 
For the second sub-period, the measures OP and FM, which are proxies for the business group control over the affiliated firm and professionalism in management, are both significant at one percent and five percent confidence levels, giving full support to hypotheses six and seven. The coefficient of the measure of OP is positive and that of FM is negative showing that the increase in the control of the group over the affiliated firms' ownership has a positive effect on firm value only when management is left more to outsiders or professionals. PAT, one of the two measures of innovativeness, is significant at one percent confidence level, giving partial support to hypothesis four. The variable diversification is not statistically significant so hypothesis five is rejected. Finally, the control variable size is significant with a positive sign implying that the firms' performance improves when groups grow in recovery times. The last control variable, industry, is not significant at the 10 percent confidence level.

A summary of hypotheses testing results are presented in Table 9.

Table 9

\section{Hypotheses Results}

\begin{tabular}{|c|c|c|c|}
\hline \multicolumn{2}{|r|}{ Hypotheses } & \multirow{2}{*}{$\begin{array}{r}\text { 2008-2010 } \\
\text { Accepted*** }\end{array}$} & \multirow{2}{*}{$\begin{array}{c}\text { 2011-2013 } \\
\text { Accepted*** }\end{array}$} \\
\hline $\mathbf{H}_{1}$ & $\begin{array}{l}\text { Business group affiliated firms have higher financial performance } \\
\text { than non-affiliated counterparts both in an economic downturn } \\
\text { and in recovery periods. }\end{array}$ & & \\
\hline $\mathbf{H}_{2}$ & $\begin{array}{l}\text { Business group affiliated firms have higher firm value than non- } \\
\text { affiliated counterparts both in an economic downturn and in } \\
\text { recovery periods. }\end{array}$ & Accepted* & Accepted** \\
\hline $\mathbf{H}_{3}$ & $\begin{array}{l}\text { Business group affiliated firms are more innovative than non- } \\
\text { affiliated counterparts both in an economic downturn and in } \\
\text { recovery periods. }\end{array}$ & Rejected & Rejected \\
\hline $\mathbf{H}_{4}$ & $\begin{array}{l}\text { There is a positive association between firm value and degree } \\
\text { of innovativeness of business group affiliated firms both in an } \\
\text { economic downturn and in recovery periods. }\end{array}$ & Rejected & Accepted $* * * * *$ \\
\hline $\mathbf{H}_{5}$ & $\begin{array}{l}\text { There is a positive association between the value of affiliated firm } \\
\text { and degree of diversification of the business group both in an } \\
\text { economic downturn and in recovery periods. }\end{array}$ & Rejected & Rejected \\
\hline $\mathbf{H}_{6}$ & $\begin{array}{l}\text { There is a positive association between the value of affiliated firm } \\
\text { and degree of control of the business group on the affiliated firm } \\
\text { both in an economic downturn and in recovery periods. }\end{array}$ & Accepted* & Accepted** \\
\hline $\mathbf{H}_{7}$ & $\begin{array}{l}\text { There is a positive association between the value of affiliated firm } \\
\text { and the degree of professionalism in management of the affiliated } \\
\text { firm both in an economic downturn and in recovery periods. }\end{array}$ & Rejected & Accepted* \\
\hline$*$ & $1 \%$ level of confidence & & \\
\hline$* *$ & $5 \%$ level of confidence & & \\
\hline *** & $10 \%$ level of confidence & & \\
\hline$* * * *$ & only for independent variable number of patents & & \\
\hline
\end{tabular}


Table 10

Findings

\begin{abstract}
Financial Performance and Firm Value and Affiliation
Business group affiliated firms have a higher financial performance and firm value than non-affiliated counterparts both in an economic downturn and in recovery periods. Among the affiliated firms, foreign firms are the best performers for firm value measured with Tobin $\mathrm{q}$ and financial performance measured with "c" for both sub-periods.
\end{abstract}

\title{
Firm Value and Innovativeness
}

There is a positive association between firm value and degree of innovativeness measured with number of patents of business group affiliated firms in recovery periods.

\section{Firm Value and Degree of Control}

There is a positive association between the value of affiliated firm and the degree of control of the business group on the affiliated firm both in an economic downturn and in recovery periods.

\section{Firm Value and Degree of Professionalism}

There is a positive association between the value of affiliated firm and the degree of professionalism in management of the affiliated firm both in recovery periods.

\section{Firm Value and Group Size}

There is a positive association between group size and the value of affiliated firm in times of crisis whereas there is a negative association between group size and the value of affiliated firm in recovery periods.

\section{Conclusion}

As shown in Table VII, the firm value measured with Tobin $\mathrm{q}$ and the financial performance measured with "c" value of the business group affiliated firms is higher than that of stand-alones. The difference is statistically significant at the 5 and 10 percent confidence levels. In an emerging economy like Turkey, the ultimate parent company seems to provide benefits to the affiliate company in terms of financial effectiveness rather than redirecting the resources of the affiliate to the parent company. The financial institutions in such economies are looking for safe collaterals like mortgages or mostly they ask for the guarantee of the parent company. In some cases, even the existence of the parent company as the controlling share behaves as a collateral. The fact of having a parent company eases the procedure of lending and moreover decreases the financial expenses charged by the financial institutions. In times of distress where it is not easy to find financial outside sources, or where it is expensive even if available, the parent company may finance the affiliate with a reasonable market rate providing a source where stand-alones face problems in attaining a source and paying the loans back on due dates. The perceived sheltering of the business group affects the firm value positively.

In a similar context, business group affiliated firms are more innovative than nonaffiliated counterparts in the sense that they have more licensed patents and, as an outcome of this, there is a positive association between the firm value and the degree of innovativeness of business group affiliated firms in recovery periods. Although the study considered the RD expenses incurred by the firm that highlight the innovativeness, the results are insignificant relative to this independent variable. For periods of crisis in which firms put limits to all spending, both variables that measure innovativeness are not significant in a regression equation. 
It is noted that the existence of a parent company empowers financial strength and firm value, and consequently the firm value is positively affected by the degree of control of the business group measured with the percentage of ownership. In the recovery periods however, professionalism in management contributes positively to firm value. As the number of board members representing the parent company decreases, the firm value decreases; this implies that the control of the parent company may not be solely for the better management of the affiliated, but rather for the business group.

As stated in the literature review section, the evidence of the effect of the business group on the financial performance of the affiliate is mixed. The findings of the present study comply with studies that document positive effects of the presence of the internal capital markets on financial performance. No association however is found with the degree of diversification of the business group and financial performance of the affiliate; hence the study supports neither diversification discount nor diversification premium.

Our results provide interesting first insights into the analysis of the relationship between corporate performance and parent company ownership in Turkish public companies. The results suggest that the affiliates benefit highly from their parents especially when the control of management is still in the affiliate itself.

The present study concentrated on innovativeness, degree of control of business group, and professionalism in management as factors contributing to the affiliate companies' firm value. The main limitation of the study is that due to time and data limitations some other factors like corporate governance index, growth potential, and risk structure that may contribute to firm value were not added to the analysis. Overall, we believe the results are thought-provoking and useful as a starting point for advancing our understanding of the governance of business groups over the affiliates in emerging economies, and we encourage researchers to continue this examination.

\section{References}

Bhagat, S. and Bolton, B. (2008). "Corporate Governance and Firm Performance," Journal of Corporate Finance, 14: 257-273.

Bebchuk, L.A. (1999). “A Rent-protection Theory of Corporate Ownership and Control,” NBER Working Paper.

Berger, P. and Ofek, E. (1995). "Diversification's Effect on Firm Value," Journal of Financial Economics, 37: 39-65.

Carney,M., Gedajlovic, E.R., Heugens, A.R., Van Essen, M., and Van Oosterhout, J. (2011). "Business Group Affiliation, Performance, Context and Strategy: A Meta Analysis," Academy of Management Journal, 54: 437-460.

Chung, K.H. and Pruitt S.W. (1994). “A Simple Approximation of Tobin's q," Financial Management, 2: 70-74.

Claessens, S., Djankov, S., and Lang, L.H.P. (2000). "The Separation of Ownership and Control in East Asian Corporations," Journal of Financial Economics, 58: 81-112.

Damanpour, F. and Evan, W.M. (1984). "Organizational Innovation and Performance: The Problem of 'Organizational Lag',” Administrative Science Quarterly, 29: 392-409. 
Demsetz, H. and Lehn, K. (1985). "The Structure of Corporate Ownership: Causes and Consequences," Journal of Political Economy, 93: 1155-1177.

Demsetz, H. and Villalonga, B. (2001). "Ownership Structure and Corporate Performance," Journal of Corporate Finance, 7: 209-233.

Desai, M., Foley, F., and Hines, J.R. (2004). “A Multinational Perspective on Capital Structure Choice and Internal Capital Markets,” Journal of Finance, 59: 2451-2487.

Donaldson, G. (1984). Managing Corporate Wealth: The Operation of a Comprehensive Financial Goals System. New York: Praeger Publishers.

Fauver, L., Houston, J., and Naranjo, A. (2001). "Capital Market Development, Legal Systems and the Value of Corporate Diversification: A Cross-Country Analysis," University of Florida Working Paper.

Himmelberg, C.P. and Petersen, B. (1994). "R\&D and Internal Finance: A Panel Study of Small Firms in High-Tech Industries," Review of Economics and Statistics: 76: 38-51.

Himmelberg, C.P., Hubbard, R.G., and Palia, D. (1999). "Understanding the Determinants of Managerial Ownership and the Link between Ownership and Performance," Journal of Financial Economics, 53: 353-384.

Hobday, M. (1995). “Innovation in East Asia: Diversity and Development,” Technovation, 15: 55-63.

Holderness, C., Kroszner, R., and Sheehan, D. (1999). "Were the Good Old Days that Good? Changes in Managerial Stock Ownership since the Great Depression?", Journal of Finance, 54: 435-469.

Khanna, T. and Palepu, K. (1997). "Why Focuses Strategies May Be Wrong for Emerging Markets," Harvard Business Review, 5: 3-10.

------, (2000a). "Is Group Affiliation Profitable in Emerging Markets? An Analysis of Diversified Indian Business Groups,” Journal of Finance. 55: 867-891.

-------, (2000b). "The Future of Business Groups in Emerging Markets: Long-Run Evidence From Chile," Academy of Management Journal, 43: 268-285.

Khanna, T. and Rivkin, J.W. (2001). "Estimating the Performance Effects of Business Groups in Emerging Markets,” Strategic Management Journal, 22: 45-74.

Kuppuswamy,V. and Villalonga, B., (2015). "Does Diversification Create Value in the Presence of External Financing Constraints? Evidence from the 2007-2009 Financial Crisis," Management Science, 62: 905-923.

La Porta R., Lopez-de-Silanes F, Shleifer A., and Vishny R. (1997). "Legal Determinants of External Finance. Journal of Finance, 52: 1131-1150.

-----, (1999). “Corporate Ownership around the World,” Journal of Finance, 54: 471-517.

Lamont, O. (1997) "Cash Flow and Investment: Evidence from Internal Capital Markets," Journal of Finance, 52: 83-109.

Lang, L.H.P. and Stulz, R.M. (1994). "Tobin's q, Corporate Diversification, and Firm Performance," Journal of Political Economy, 102: 1248-1280.

Lins, K.V. and Servaes, H. (1999). "International Evidence on the Value of Corporate Diversification," The Journal of Finance, 54: 2215-2239.

Lins, K.V. (2000). "Equity Ownership and Firm Value in Emerging Markets," The Journal of Financial and Quantitative Analysis, 38: 159-184. 
Morck, R., Shleifer, A., and Vishny, R. (1988). "Management Ownership and Market Valuation: An Empirical Analysis," Journal of Financial Economics, 20: 293-315.

Rajan, R., Servaes, H., and Zingales, L. (2000). "The Cost of Diversity: The Diversification Discount and Inefficient Investment," The Journal of Finance, 55: 35-80.

Scharfstein, D. (1998). "The Dark Side of Internal Capital Markets II: Evidence from Diversified Conglomerates," NBER Working paper No. 6352.

Servaes, H. (1996). "The Value of Diversification during the Conglomerate Merger Wave," The Journal of Finance, 51: 1201-1225.

Shin, H. and Stulz, R. (1998). "Are Internal Capital Markets Efficient?," Quarterly Journal of Economics, 113: 531-55.

Shin, H. and Park, Y.S. (1999). "Financing Constraints and Internal Capital Markets: Evidence from Korean 'chaebols',' Journal of Corporate Finance, 5: 169-191.

Stein, J.C. (1997). "Internal Capital Markets and the Competition for Corporate Resources," The Journal of Finance, 52: 111-133.

Subramanian A. and Nilakanta, S. (1996). "Organizational Innovativeness: Exploring the Relationship between Organizational Determinants of Innovation, Types of Innovations, and Measures of Organizational Performance." Omega, 24: 631-647.

Sytse, D., Rejie, G., and Rezaul, K. (2006). "Foreign and Domestic Ownership, Business Groups and Firm Performance: Evidence from a Large Emerging Market," Strategic Management Journal, 27: 637-657.

Teece, D.J. (1996). "Firm Organization, Industrial Structure, and Technological Innovation," Journal of Economic Behavior and Organization," 31: 193-224.

Torben, P., and Thomsen, S. (2000). "Ownership Structure and Value of the Largest European Firms: The Importance of Owner Identity," Journal of Management and Governance, 7: 27-55.

Uygurtürk, H. and Korkmaz, T. (2012). "The Determination of Financial Performance with TOPSIS Multiple Criteria Decision Making Method: An Application on Basic Metal Industry Enterprises," Eskisehir Osmangazi Üniversitesi İ̇BF Dergisi, 7: 95-115.

Üsdiken, B. (2008). "Business Groups in Turkey: Introduction to the Special Issue," Yönetim Araştırmaları Dergisi, 8: 5-21.

Üsdiken, B. and Öktem, O.Y. (2008). "Changes in the Institutional Environment and Non-Executive and Independent Directors on the Boards of the Firms Affiliated to Large Family Business Groups," Amme İdaresi Dergisi, 41: 43-71.

Villalonga B. and Amit R. (2006). "How do Family Ownership, Control and Management Affect Firm Value?," Journal of Financial Economics, 80: 385-417.

Wenyi, C. (2004). “Are Group-Affiliated Firms Really More Profitable than Non- Affiliated?,” Small Business Economics, 22: 391-405.

Williamson, O.E. (1975). Markets and Hierarchies: Analysis and Antitrust Implications. New York: Free Press. 